\title{
Joanna Narodowska
}

joanna.narodowska@uwm.edu.pl

Uniwersytet Warmińsko-Mazurski w Olsztynie

Katedra Kryminologii i Polityki Kryminalnej

al. Warszawska 98

10-702 Olsztyn

Maciej Duda

maciej.duda@uwm.edu.pl

Uniwersytet Warmińsko-Mazurski w Olsztynie

Katedra Kryminologii i Polityki Kryminalnej

al. Warszawska 98

10-702 Olsztyn

\section{Wandalizm zabytków \\ z perspektywy kryminologicznej \\ Vandalism of monuments \\ from the criminological perspective}

Summary: In this paper the authors discuss issues referring to the vandalism of monuments from the criminological perspective. They present the legal definition of criminal acts of vandalism. The paper begins by pointing out selected etiological factors. The main focus of the paper is on the phenomenology of vandalism of monuments. In this part, the specific forms of monument vandalism which appear very often in north-eastern Poland (Warmia, Masuria, Podlasie) are characterised. Furthermore, the paper presents the phenomenology of issues such as: ideological vandalism, vandalism of archaeological monuments, vandalism by omission, and vandalism of cultural landscape. By confronting linguistic and doctrinal definitions of vandalism with the phenomenon as it occurs in practice, the authors create their own definition of the vandalism of monuments.

Keywords: vandalism, monuments, cultural heritage, destruction, criminology 


\section{ARTYKUŁY}

Joanna Narodowska, Maciej Duda

Streszczenie: Autorzy artykułu poruszają problematykę wandalizmu zabytków postrzeganego z perspektywy kryminologicznej. Przedstawiają ponadto prawnokarną kwalifikację czynów o charakterze wandalskim. Wskazują na wybrane czynniki etiologiczne tej patologii. Główny wątek rozważań poświęcony jest fenomenologii wandalizmu zabytków. Autorzy charakteryzują specyficzne formy wandalizmu zabytków, występujące w szczególności w Polsce Północno-Wschodniej (Warmia, Mazury, Podlasie). Omówione zostały takie aspekty zjawiska jak: wandalizm ideologiczny, wandalizm zabytków archeologicznych, wandalizm przez zaniechanie oraz wandalizm krajobrazu kulturowego. Poprzez skonfrontowanie językowych i doktrynalnych definicji wandalizmu z występującymi w praktyce formami tego zjawiska autorzy formułują własną propozycję definicji wandalizmu zabytków.

Słowa kluczowe: wandalizm, zabytki, dziedzictwo kulturowe, destrukcja, kryminologia

\section{Wstęp}

Rozważania dotyczące kryminologicznej i prawnokarnej oceny zjawiska wandalizmu zabytków rozpocząć należy od stwierdzenia, że już etymologicznie pojęcie wandalizmu łączy się z dziedzictwem kulturowym. Od czasów rewolucji francuskiej pojęciem tym określano bowiem wielkie, masowe niszczenie dóbr kultury danego narodu, nawiązując do grabieży i zniszczeń dokonanych w Rzymie w 455 r. n.e. przez Wandalów ${ }^{1}$.

Współcześnie w literaturze prawniczej, kryminologicznej, socjologicznej i psychologicznej istnieje wiele, nie zawsze zbieżnych, definicji wandalizmu. W obszarze nauk penalnych największą popularnością cieszy się definicja wandalizmu sensu stricto sformułowana przez Andrzeja Siemaszko, który za wandalizm uznaje „umyślne niszczenie mienia nie należącego do sprawcy bez powodów łatwo uchwytnych dla osoby niszczącej bądź dla osoby oceniającej takie działania". Jednocześnie autor ten, zdając sobie sprawę z niepełności tej definicji, wskazuje, że najprawdopodobniej wandalizm jest w ogóle niedefiniowalny². Natomiast zgodnie z definicją językową wandalizm to rozmyślne niszczenie jakichś dóbr i wartości, zwłaszcza kulturalnych ${ }^{3}$.

1 K. Ostrowska, Psychologiczne aspekty wandalizmu nieletnich, w: B. Hołyst (red.), Wandalizm. Aspekty socjologiczne, psychologiczne i prawne, PWN, Warszawa 1984, s. 88.

2 A. Siemaszko, Wandalizm - definicja, etiologia, zapobieganie, w: B. Hołyst (red.), op. cit., s. 32-33.

3 Wandalizm [hasło], w: M. Szymczak (red.), Słownik języka polskiego, t. III, Warszawa 1979, s. 655. 
Celem niniejszego artykułu jest ukazanie na wybranych przykładach, że wandalizm zabytków, z uwagi na złożoną etiologię i wielowymiarową fenomenologię, powinien być ujmowany znacznie szerzej. Kryminologiczne pojęcie wandalizmu sensu largissimo obejmuje bowiem czyny o różnorodnym charakterze i modus operandi sprawców oraz podlegające zróżnicowanej kwalifikacji prawnokarnej lub wręcz wymykające się takiej ocenie. Autorzy podejmują również próbę zdefiniowania zjawiska wandalizmu zabytków w odniesieniu do dotychczasowych, ogólnych definicji zjawiska wandalizmu oraz przedstawionych kryminologicznych form objawowych tej patologii.

\section{Prawnokarna kwalifikacja czynów wandalskich}

W ciągu ostatnich stu lat polskie prawo ochrony dziedzictwa kultury kształtowane było przez cztery kolejne akty prawne: dekret Rady Regencyjnej o opiece nad zabytkami sztuki i kultury z 1918 r. ${ }^{4}$ (dalej: dekret), rozporządzenie Prezydenta Rzeczypospolitej o opiece nad zabytkami z 1928 r. ${ }^{5}$ (dalej: rozporządzenie), ustawę o ochronie dóbr kultury z 1962 r. ${ }^{6}$ (dalej: u.o.d.k.) oraz ustawę o ochronie zabytków i opiece nad zabytkami z 2003 r. ${ }^{7}$ (dalej: u.o.z).

W aktualnie obowiązującej ustawie niszczenie lub uszkadzanie zabytku stanowi występek z art. 108 u.o.z. Ponadto w art. 110 u.o.z. spenalizowano, jako wykroczenie, zachowanie polegające na niezabezpieczeniu zabytku w należyty sposób przed uszkodzeniem, zniszczeniem, zaginięciem lub kradzieżą przez jego właściciela lub posiadacza zabytku.

Warto zwrócić również uwagę na genezę tych przepisów. W pierwotnej wersji ustawy o ochronie dóbr kultury przewidziane było $w$ art. 73 przestępstwo uszkodzenia lub zniszczenia zabytku, jednakże na skutek wejścia w życie w 1998 r. Kodeksu karnego (dalej: k.k.) odpowiednik aktualnego przestępstwa z art. 108 u.o.z. utracił moc obowiązującą9. W art. 78 u.o.d.k. spenalizowane zostało natomiast wykroczenie polegające na niezabezpieczeniu przez właściciela lub użytkownika zabytku przed zniszczeniem, dewastacją lub uszkodzeniem, stanowiące zatem od-

\footnotetext{
4 Dekret Rady Regencyjnej z dnia 31 października 1918 r. o opiece nad zabytkami sztuki i kultury, „Dziennik Praw” 1918, nr 16.

5 Rozporządzenie Prezydenta Rzeczypospolitej z dnia 6 marca 1928 r. o opiece nad zabytkami, Dz. U. Nr 29, poz. 265.

6 Ustawa z dnia 15 lutego 1962 r. o ochronie dóbr kultury, Dz. U. Nr 10, poz. 48.

7 Ustawa z dnia 23 lipca 2003 r. o ochronie zabytków i opiece nad zabytkami, tekst jedn. Dz. U. z 2014 r., poz. 1446.

8 Ustawa z dnia 6 czerwca 1997 r. Kodeks karny, Dz. U. Nr 88, poz. 553 ze zm.

9 W. Radecki, Ochrona dóbr kultury w nowym kodeksie karnym, „Prokuratura i Prawo” 1998, nr 2, s. 7-20. Osłabienie prawnokarnej ochrony zabytków poprzez derogację art. 73 u.o.d.k. spotkało się z krytyką w doktrynie. Zob. J. Kaczmarek, K. Zeidler, Prawnokarna ochrona zabytków, „Prokuratura i Prawo” 2004, nr 2, s. 80-81.
} 


\section{ARTYKUŁY}

Joanna Narodowska, Maciej Duda

powiednik aktualnego wykroczenia z art. 110 u.o.z. Zarówno rozporządzenie, jak i dekret penalizowały $\mathrm{w}$ formie wykroczeń zachowania polegające na niszczeniu zabytków. W art. 36 rozporządzenia przewidziane było wykroczenie polegające na naruszeniu przepisów zakazujących m.in. burzenia, rozkopywania, niszczenia, przerabiania zabytków (art. 14 rozporządzenia). W art. 34 dekretu zawarte było analogiczne wykroczenie polegające na przekroczeniu przepisów dekretu. Burzenia, niszczenia i przerabiania zakazywał natomiast art. 13 (w stosunku do zabytków nieruchomych) oraz art. 20 (w stosunku do zabytków ruchomych).

Jak wskazuje się w literaturze, polski system prawnokarnej ochrony dziedzictwa kulturowego ma charakter półkodeksowy ${ }^{10}$. W związku z tym kwalifikacja zachowań o charakterze wandalskim polegających na niszczeniu mienia może nastąpić na gruncie Kodeksu karnego lub Kodeksu wykroczenn ${ }^{11}$ (dalej: k.w.) bądź na gruncie ustawy o ochronie zabytków i opiece nad zabytkami Jeżeli zniszczona lub uszkodzona rzecz stanowi zabytek w rozumieniu art. 3 u.o.z., zastosowanie znajdzie art. 108 u.o.z., kryminalizujący niszczenie lub uszkadzanie zabytku. Mienie uznane może być za zabytek, jeżeli jest świadectwem minionej epoki bądź zdarzenia, których zachowanie leży w interesie społecznym ze względu na jego wartość historyczną, artystyczną lub naukową. Dla bytu tego przestępstwa nie ma przy tym znaczenia, czy jest to zabytek wpisany do rejestru zabytków oraz czy zabytek jest rzeczą cudzą dla sprawcy ${ }^{12}$. Jeżeli zniszczona lub uszkodzona rzecz nie będzie miała waloru zabytku (np. współczesne dzieło sztuki), wówczas odwołać się należy do przepisów Kodeksu karnego, mając w szczególności na uwadze wartość zarówno materialną, jak i kulturową danej rzeczy. Konstrukcja czynów przepołowionych powoduje, że niszczenie lub uszkadzanie cudzej rzeczy powodujące szkodę nieprzekraczającą 1/4 minimalnego wynagrodzenia skutkuje kwalifikacją z art. 124 k.w. Za wykrocznie to przewidziana jest kara aresztu, ograniczenia wolności albo grzywny. Przekroczenie tej kwoty granicznej implikuje kwalifikację czynu z art. 288 k.k. W przypadku gdy przedmiot zamachu uznany jest za dobro o szczególnym znaczeniu dla kultury, właściwe będzie zastosowanie typu kwalifikowanego z art. 294 $\S 2$ k.k., za który grozi kara pozbawienia wolności od roku do 10 lat. Ponadto sposób i okoliczności działania sprawcy czynów o charakterze wandalskim, takie jak umyślność czynu, niszczenie lub uszkadzanie cudzej rzeczy, publiczność działania, brak powodu lub oczywiście błahy powód, lekceważenie porządku prawnego, powodują, że w świetle art. 115 § 21 k.k. jego czyn może mieć charakter chuligański, co skutkuje obostrzeniem kary na podstawie art. 57a k.k.

10 B. Gadecki, Ustawa o ochronie zabytków i opiece nad zabytkami. Art. 108-120. Przepisy karne. Komentarz, C.H. Beck, Warszawa 2014, s. VII.

11 Ustawa z dnia 20 maja 1971 r. Kodeks wykroczeń, tekst jedn. Dz. U. z 2015 r., poz. 1094, ze zm.

12 A. Gerecka-Żołyńska, Rozważania wokół współczesnych problemów karnoprawnej i karnoprocesowej ochrony zabytków, w: W. Szafrański (red.), Wokół problematyki prawnej zabytków i dzieł sztuki, t. 2, Wydawnictwo Poznańskie, Poznań 2008, s. 134. 
Zauważyć należy, że sankcja karna za naruszenie dyspozycji art. 108 § 1 u.o.z. oraz art. $288 \S 1$ k.k. jest identyczna i wynosi od 3 miesięcy do 5 lat pozbawienia wolności. Jednakże zakres prawnokarnej ochrony zabytków w porównaniu do innego mienia jest znacznie szerszy. Zgodnie z dyspozycją art. 288 k.k., przedmiotem zamachu jest rzecz cudza. Ustawa o ochronie zabytków nie wyłącza z kręgu podmiotów, które mogą być pociągnięte do odpowiedzialności karnej za niszczenie lub uszkadzanie zabytku, ich właścicieli. Innymi słowy, przedmiotem zamachu z art. 108 u.o.z. jest zabytek cudzy oraz własny. Z perspektywy prawnokarnej oraz kryminologicznej zjawisko wandalizmu zabytków może polegać na działaniu sprawcy lub zaniechaniu, czyli powstrzymaniu się od działania. Dla tego typu zachowań zaproponować można zatem pojęcia „wandalizm z działania” $i$ „wandalizm z zaniechania”. W zależności od formy czynu podmiot przestępstwa z art. 108 u.o.z. będzie miał charakter powszechny lub indywidualny. Jest to występek materialny (skutkowy), wobec czego z zaniechania odpowiadać będzie wyłącznie podmiot, na którym ciąży szczególny prawny obowiązek zapobiegnięcia skutkowi, tj. właściciel lub posiadacz samoistny. Zasygnalizować trzeba, że strona podmiotowa czynu z art. 288 k.k. obejmuje jedynie umyślność, natomiast nieumyślne niszczenie lub uszkadzanie cudzej rzeczy nie jest kryminalizowane. W odniesieniu do zabytków sankcja karna przewidziana jest także za nieumyślne wypełnienie znamion tego czynu zabronionego (art. 108 $\S 2$ u.o.z.). Kara to grzywna, ograniczenie wolności albo pozbawienie wolności do 2 lat. Jednocześnie nieumyślne niszczenie lub uszkadzanie zabytku jest jedynym typem uprzywilejowanym tego przestępstwa. Ustawodawca nie przewidział wypadku mniejszej wagi, tak jak ma to miejsce na gruncie Kodeksu karnego w art. 288 § 2.

\section{Etiologia wandalizmu zabytków}

Zachowania o charakterze wandalskim mogą mieć różnorodne przyczyny. Wśród najczęstszych wskazuje się na chęć rozładowania nagromadzonej w człowieku energii, wyładowanie frustracji i agresji, sprzeciw wobec danej grupy lub osoby, zazdrość o czyjąś własność, kompleks niższości lub wyższości, brak szacunku dla pracy, niechęć do uprzedmiotowionej idei albo stylu ${ }^{13}$. Wydaje się jednak, że szerokie ujęcie zjawiska wandalizmu implikuje konieczność uwzględnienia wśród przyczyn wandalizmu również innych motywacji, m.in. ideologicznej lub ekonomicznej. Wymienione determinanty nie wyczerpują oczywiście katalogu przyczyn wandalizmu dziedzictwa kulturowego, o czym świadczy chociażby słynny przykład szewca Herostratesa, który w 356 r. p.n.e. podpalił Artemizjon w Efezie z chęci zdobycia wiecznej sławy, co mu się niewątpliwie udało. Na gruncie kryminologicznym nie podjęto do tej pory próby stworzenia kompleksowej teorii wyjaśniającej przestępczość wobec dziedzictwa kulturowego. Jednakże niektóre z dotychczas wypracowanych teorii mogą znaleźć zastosowanie w wyjaśnieniu etiologii tego fenomenu.

13 B. Hołyst, Przyczyny i przejawy wandalizmu, w: B. Hołyst (red.), op. cit., s. 12-13. 


\section{ARTYKUEY}

Joanna Narodowska, Maciej Duda

Wśród nich wskazać można m.in. następujące teorie: frustracji i agresji, konfliktu kultur, podaży okazji przestępczych, anomii, wybitych szyb oraz ekonomiczne teorie przestępczości ${ }^{14}$. Ponadto wyselekcjonowanie czynników, które odgrywają główną rolę w procesie kryminogenezy wandalizmu dziedzictwa kulturowego, wymaga przeprowadzenia pogłębionych badań kryminologicznych.

\section{Fenomenologia wandalizmu zabytków}

Wandalizm uznawany jest za jedną z niedocenianych form przestępczości skierowanej przeciwko dziedzictwu kulturowemu ${ }^{15}$. W literaturze poświęconej przestępczości przeciwko dziedzictwu kulturowemu wielokrotnie opisywano klasyczne akty wandalizmu towarzyszące takim przestępstwom jak: grabież wojenna ${ }^{16}$, przestępstwa terrorystyczne ${ }^{17}$, kradzież $^{18}$, przemyt ${ }^{19}$ lub fałszerstwa dóbr kultu$r y^{20}$.W niniejszym artykule autorzy skupili się wyłącznie na specyficznych formach wandalizmu zabytków charakterystycznych dla Polski Północno-Wschodniej.

\section{a) Wandalizm ideologiczny}

Jedną z odmian wandalizmu według kryminologicznej typologii Stanleya Cohena jest wandalizm ideologiczny ${ }^{21}$. Szczególnie eskalującą w ostatnich latach i społecz-

14 Zob. szerzej J. Błachut, A. Gaberle, K. Krajewski, Kryminologia, Arche, Gdańsk 2001.

15 P. Ogrodzki, Przestępczość przeciwko zabytkom (krótka charakterystyka zjawiska), w: M. Karpowicz, P. Ogrodzki (red.), Międzynarodowa współpraca służb policyjnych, granicznych i celnych w zwalczaniu przestępczości przeciwko zabytkom, Wydział Wydawnictw Wyższej Szkoły Policji, Szczytno 2005, s. 140.

16 Grabieżywojennych dokonywaliwubiegłymtysiącleciunaterenie PolskiCzesi,Szwedzi, Rosjanie, Niemcy. Jednocześnie rewindykacja dóbr kultury postępuje w niewystarczającym tempie. Zob. szerzej: M. Lewicka, W świecie zabytków sztuki, Wydawnictwa Szkolne i Pedagogiczne, Warszawa 1976, s. 144-145; S. Waltoś, Grabież ołtarza Wita Stwosza, Wolters Kluwer, Warszawa 2015; M. Marcinkowska, Rewindykacja muzealiów z Rosji, w: J. Włodarski, K. Zeidler (red.), Prawo muzeów, Wolters Kluwer Polska, Warszawa 2008, s. 181-190.

17 Wskazuje się tutaj na zjawisko tzw. artnapingu czyli terrorystycznego szantażu, którego przedmiotem stają się dzieła sztuki i zabytki, np. zamach na Galerię Uffizi lub zaminowanie antycznych zabytków Palmiry przez bojowników Państwa Islamskiego (ISIS). Zob. M. Trzciński, O niszczeniu zabytków, w: W. Pływaczewski, B. Gadecki (red.), Ochrona dziedzictwa kulturalnego i naturalnego. Perspektywa prawna i kryminologiczna, C.H. Beck, Warszawa 2015, s. 144-145.

18 Przykładem zniszczenia dóbr kultury niejako przy okazji ich kradzieży mogą być kradzieże sarkofagu św. Wojciecha z katedry gnieźnieńskiej, obrazu Claude’a Moneta Plaża w Pourville z Muzeum Narodowego w Poznaniu lub napisu „Arbeit macht frei” z Muzeum w Oświęcimiu. Zob. V. Zunkovic, To tylko znak, Studio „Avalon”, Olsztyn 2012.

19 Przy przemycie dóbr kultury niejako ubocznym skutkiem może być ich uszkodzenie lub zniszczenie, np. wycinanie obrazów z ram i ich rolowanie lub składanie, oderwanie fragmentów przewożonych zabytków. 20 Zniszczenie lub uszkodzenie dobra kultury przy okazji fałszerstwa może nastąpić podczas jego przerabiania poprzez tzw. postarzanie.

21 Szerzej na temat kulturowych konotacji pojęcia „ideologia” w: J. Szacki, Ideologia, w: A. Kłoskowska (red.), Encyklopedia kultury polskiej XX wieku, t. 1: Pojęcia i problemy wiedzy o kulturze, „Wiedza o Kulturze”, Wrocław 1991, s. 189-202. 
nie szkodliwą formą wandalizmu motywowanego ideologicznie jest graffiti o charakterze przestępstw z nienawiści. Polega to na umieszczaniu w przestrzeni publicznej, w tym na zabytkach, wizualnych przejawów ekstremistycznych ideologii, w szczególności o charakterze antysemickim i antyislamskim. Mogą one przybrać postać napisów, haseł, symboli graficznych, cyfrowych, literowych, skrótowców. Sprawcami tego typu incydentów definiowanych jako mowa nienawiści są najczęściej członkowie grup neonazistowskich, nacjonalistycznych, pseudokibiców, subkultury skinhead lub satanistów. Jak podkreśla Wiesław Pływaczewski, wizualny wandalizm ideologiczny jest to forma zawłaszczania przestrzeni publicznej przez patologiczne subkultury oraz przejaw degradacji historycznej, zabytkowej przestrzeni miejskiej ${ }^{22}$. Zjawisko to przybrało szczególnie niebezpieczne rozmiary na Podlasiu. Jako przykłady można podać następujące zdarzenia:

- profanacja w rocznicę powstania $\mathrm{w}$ getcie białostockim zabytkowego cmentarza żydowskiego w Białymstoku, na którym umieszczono antysemickie napisy: „Arbeit macht frei” $i$,Jude rauss” oraz swastyki i powieszone gwiazdy Dawida,

- zamalowanie pomnika pomordowanych w Jedwabnem antysemickimi hasłami: „Nie przepraszam za Jedwabne” i „Byli łatwopalni” oraz swastykami i symbolami SS,

- namalowanie na zabytkowym drewnianym meczecie w Kruszynianach symboli Polski Walczącej oraz świni, która dla muzułmanów jest zwierzęciem nieczystym,

- umieszczenie na ścianach synagogi w Orli antysemickich haseł: "Cała Polska dla Polaków” $i$ „White Power” oraz namalowanie swastyki ${ }^{23}$.

W przypadku, gdy wandalizm o charakterze ideologicznego graffiti doprowadzi do nieodwracalnego uszkodzenia substancji zabytkowej, zachodzić może zbieg przestępstwa uszkodzenia zabytku z art. 108 u.o.z. z przestępstwami nawoływania do nienawiści z art. 256 k.k. lub publicznego znieważenia grupy lub osoby z art. 257 k.k.

Do przejawów wandalizmu ideologicznego można zaliczyć w pewnym sensie również negatywny stosunek władz i społeczeństwa do poniemieckiej spuścizny kulturowej na Ziemiach Odzyskanych, w szczególności w byłych Prusach Wschodnich. Pozostawione przez autochtonów zabytki ruchome były rozkradane, a zabytki nieruchome niszczone przez osiedleńców lub w najlepszym przypadku zamie-

22 W.Pływaczewski, Wandalizmz perspektywyochrony dziedzictwa kultury-diagnozazjawiska oraz możliwości przeciwdziałania, w: K. Zeidler (red.), Prawo ochrony zabytków, Wolters Kluwer, Wydawnictwo Uniwersytetu Gdańskiego, Warszawa - Gdańsk 2014, s. 538-539; idem, Zawłaszczanie przestrzeni przyrodniczej i kulturowej - uwagi na tle zjawiska dewastacji krajobrazu, w: W. Pływaczewski, B. Gadecki (red.), op. cit., s. 17-18.

23 E. Czajkowska, M. Truskolaska, Wandalizm dzieł sztuki jako wizualny przejaw nienawiści na przykładzie województwa podlaskiego, w: W. Pływaczewski, P. Lubiewski (red.), Współczesne ekstremizmy. Geneza, przejawy, przeciwdziałanie, Katedra Kryminologii i Polityki Kryminalnej. Wydział Prawa i Administracji Uniwersytetu Warmińsko-Mazurskiego, Olsztyn 2014, s. 152-156; W. Pływaczewski, Wandalizm wobec dziedzictwa kulturowego jako przejaw nienawiści o podłożu ideologicznym, w: M. Różański, N. Kasparek (red.), Ochrona dóbr kultury. Aktualne wyzwania, Archidiecezjalne Wydawnictwo Łódzkie, Olsztyn 2016, s. 51-62. 


\section{ARTYKUŁY}

Joanna Narodowska, Maciej Duda

niane na budynki gospodarcze PGR-ów. Proceder ten odbywał się przy aprobacie komunistycznych władz, chcących w ten sposób zatrzeć ślady obecności narodu niemieckiego. Jak wskazuje W. Pływaczewski, w ten sposób nienawiść do wroga przenoszona była na stworzone przez niego dziedzictwo kulturowe ${ }^{24}$. Na społeczne postrzeganie poniemieckiej spuścizny kulturowej w drugiej połowie XX w. większy wpływ niż względy ochrony dziedzictwa kulturowego miały zatem kwestie ideologiczno-polityczne ${ }^{25}$.

\section{b) Wandalizm zabytków archeologicznych}

Za wandalizm uznać można również rabunkowe, inwazyjne poszukiwania zabytków archeologicznych i wykopaliska na stanowiskach archeologicznych prowadzone przez tzw. detektorystów, czyli poszukiwaczy amatorów posługujących się magnetometrami (wykrywaczami metalu) ${ }^{26}$. Zachowanie takie godzi w prawidłowość prowadzenia poszukiwań ukrytych lub porzuconych zabytków ${ }^{27}$. Już samo prowadzenie tego typu poszukiwań bez właściwego zezwolenia lub wbrew zezwoleniu wypełnia znamiona wykroczenia $z$ art. 111 u.o.z. Ponadto w trakcie wydobywania ruchomych zabytków archeologicznych ze stanowiska archeologicznego następuje często ich bezpowrotne oderwanie od kontekstu kulturowego, co powoduje nieodwracalną stratę dla kultury i nauki, gdyż uniemożliwia podjęcie profesjonalnych prac archeologicznych ${ }^{28}$. Sprawcy, zainteresowani nierzadko jedynie przedmiotami posiadającymi wartość handlową, niszczą bezpowrotnie pozostałe przedmioty i nawarstwienia kulturowe nieprzedstawiające dla nich żadnej wartości.

Podkreślić należy, że działalności eksploracyjnej nie wolno utożsamiać wyłącznie z negatywnymi skutkami. Wielu detektorystów to miłośnicy historii, których pasją jest odkrywanie materialnych śladów przeszłości. Prowadzą oni poszukiwania w granicach prawa, znalezione przedmioty zabezpieczają, a następnie przekazują do właściwych instytucji. Pokusić się można nawet o stwierdzenie, że działalność wy-

24 W. Pływaczewski, Wandalizm wobec..., s. 51-62.

25 E. Łukaszewicz-Jędrzejewska, Trudne dziedzictwo - zabytki Dolnego Śląska „jako źródło kształtowania i wychowania nowego człowieka", w: E. Pilecka, J. Raczkowski (red.), Wobec zabytku... tradycje i perspektywy postaw, Wydawnictwo Naukowe Uniwersytetu Mikołaja Kopernika, Toruń 2010, s. 158-167. Z podobnym problemem stosunku do zabytków wzniesionych przez zaborców musiało zmierzyć się państwo polskie również po $1918 \mathrm{r}$.

26 Kwestia szkodliwości amatorskich poszukiwań archeologicznych podniesiona została już w połowie XX w. Natomiast na problem wykorzystania wykrywaczy metali zwrócono uwagę w doktrynie na początku XXI w. Por. B. Kostrzewski, Ochrona zabytków przedhistorycznych, „Czytelnik”, Łódź 1948, s. 7-21; A. Bursche, Złodzieje i paserzy, dogmatycy i moraliści, „Światowid” 2000, nr 2(43), s. 43-52.

27 B. Gadecki, Ustawa o ochronie zabytków..., s. 102.

28 M. Trzciński, Kryminalistyczne i kryminologiczne aspekty przestępstw przeciwko zabytkom archeologicznym, „Państwo i Prawo” 2007, nr 3, s. 30; W. Kowalski, Cywilnoprawne aspekty obrotu skradzionymi dobrami kultury, w: J. Kaczmarek (red.), Prawnokarna ochrona dziedzictwa kultury, Zakamycze, Kraków 2006, s. 58. Prawidłowe metody prowadzenia prac archeologicznych przedstawiono w: M. Trzciński (red.), Archeologia sądowa w teorii i praktyce, Wolters Kluwer Polska, Warszawa 2013, a prawne aspekty takiej działalności w: K. Zeidler, M. Trzciński, Wykład prawa dla archeologów, Wolters Kluwer Polska, Warszawa 2009. 
krywcza - jeśli jest prowadzona z poszanowaniem prawa - przyczyniać się może do wzbogacania dziedzictwa kultury. Detektoryści poszukują często w miejscach, w których nie przypuszczano by nawet, że znajdują się zabytki archeologiczne ${ }^{29}$.

Wykroczenie prowadzenia nielegalnych poszukiwań z art. 111 u.o.z. pozostawać może zatem $w$ zbiegu z przestępstwem zniszczenia lub uszkodzenia zabytku z art. 108 u.o.z. Już po zakończeniu czynności poszukiwania dojść może ponadto do przywłaszczenia zabytku (art. 284 k.k.) lub jego kradzieży (art. 278k.k.), a wzwiązku z obrotem zabytkami również do oszustwa (art. 286 § 1 k.k.) lub paserstwa (art. 291 $\S 1$ k.k.). Jeżeli zabytek miał walor dobra o szczególnym znaczeniu dla kultury, zastosowanie znajdzie typ kwalifikowany (art. 294 § 2 k.k. ${ }^{30}$. Podkreślenia wymaga również fakt, że negatywnym skutkiem działalności eksploratorów jest stymulowanie nielegalnego obrotu artefaktami, w szczególności za pośrednictwem Internetu ${ }^{31}$. Na marginesie jedynie zaznaczyć można, że dokonując tego typu poszukiwań na obszarach leśnych, które stanowią ponad 30\% obszaru Warmii i Mazur, można popełnić również wykroczenia stypizowane w rozdziale XIX Kodeksu wykroczeń, zatytułowanym „Szkodnictwo leśne, polne i ogrodowe”32. Obiektami szczególnie narażonymi na amatorską eksplorację archeologiczną w północno-wschodniej Polsce są liczne kurhany, wały i grodziska pruskie ${ }^{33}$. Inną, specyficzną odmianą nielegalnych poszukiwań zabytków jest poszukiwanie podwodnych zabytków archeologicznych przez eksploratorów wyposażonych akwalungi i wykrywacze metali ${ }^{34}$. Obiektami takiej penetracji w województwie warmińsko-mazurskim są w szczególności zatopione osady Galindów nad Wielkimi Jeziorami Mazurskimi. Ponadto

29 Zob. szerzej: M. Duda, J. Narodowska, Eksploracja archeologiczna obszarów leśnych, w: W. Pływaczewski, M.Duda(red.), Nielegalna eksploatacja obszarówleśnych, Katedra Kryminologii i Polityki Kryminalnej. Wydział Prawa i Administracji. Uniwersytet Warmińsko-Mazurski, Olsztyn 2013, s. 192-203; M. Duda, Nielegalne poszukiwania zabytków jako zagrożenie dla dziedzictwa kulturalnego, w: W. Pływaczewski, B. Gadecki (red.), op. cit., s. 152-170.

30 Ponieważ właścicielem zabytków archeologicznych jest Skarb Państwa, każde ich bezprawne posiadanie (zarówno celowa eksploracja, jak i przypadkowe znalezienie) spełnia znamiona przestępstwa przywłaszczenia (K. Zeidler, M. Trzciński, op. cit., s. 75). W tym kontekście zwrócić należy również uwagę na podjętą w literaturze dyskusję nad propozycją prywatyzacji zabytków archeologicznych. Zob. L. Czerniak, Niechciane zabytki archeologiczne, w: J. Włodarski, K. Zeidler (red.), op. cit., s. 120-121.

31 W. Pływaczewski, Zawłaszczanie przestrzeni..., s. 25-26.

32 W szczególności art. 148, 152, 153, 154, 156, 161, 163, 164, 166 k.w. Szerzej na ten temat w: M. Duda, J. Narodowska, op. cit., s. 192-203.

33 Zakrojone na szeroką skalę badania archeologicznego dziedzictwa Prusów przeprowadził w latach 20. XX w. łotewski archeolog Feliks Jakobson. Zob. T. Nowakiewicz (red.), Archeologiczne dziedzictwo Prus Wschodnich w archiwum Feliksa Jakobsona, Ministerstwo Kultury i Dziedzictwa Narodowego. Departament Dziedzictwa Kulturowego, Warszawa 2011.

34 Problematyce tej poświęcono monografię: B. Gadecki, Ochrona podwodnego dziedzictwa kultury aspekty prawnokarne i kryminologiczne, C.H. Beck, Warszawa 2014. Autor ten zauważa, że dla zapewnienia pełniejszej ochrony podwodnego dziedzictwa kulturowego należałoby wprowadzić do ustawy o ochronie zabytków i opiece nad zabytkami nowy typ wykroczenia, polegający na posiadaniu bez zezwolenia wykrywacza metalu w strefach ochronnych utworzonych wokół zatopionych zabytków. Podyktowane jest to problemami dowodowymi pojawiającymi się w ściganiu wykroczeń z art. 111 u.o.z. 


\section{ARTYKUŁY}

Joanna Narodowska, Maciej Duda

zwrócić należy uwagę na niszczenie zabytków archeologicznych przy okazji inwestycji gospodarczych, w szczególności budowy autostrad i dróg ekspresowych ${ }^{35}$. Niepoinformowanie organów konserwatorskich o odkryciu zabytku podczas robót budowlanych lub ziemnych jest wykroczeniem z art. 115 u.o.z., a kontynuowanie tych prac skutkujące zniszczeniem lub uszkodzeniem zabytku jest przestępstwem z art. 108 u.o.z. Inwestorzy lub wykonawcy nierzadko próbują ukryć fakt znalezienia zabytków z obawy przed opóźnieniem procesu realizacji inwestycjiji

\section{c) Wandalizm przez zaniechanie}

Prima facie czyny wandalskie polegają na działaniu. Wydaje się jednak, że w pewnych warunkach za wandalizm uznany może być brak działania, czyli zaniechanie. Jak wskazuje się w literaturze, w polskich realiach równie wielkim zagrożeniem dla zabytków jak świadomy wandalizm jest bezczynnośći bierność ich właścicieli oraz organów administracji37. Artykuł 5 u.o.z. wskazuje bowiem, że na właścicielu lub posiadaczu zabytku spoczywa obowiązek zapewnienia warunków do prowadzenia prac konserwatorskich, restauratorskich i robót budowlanych przy zabytku; zabezpieczenia i utrzymania zabytku oraz jego otoczenia w jak najlepszym stanie; korzystania z zabytku w sposób zapewniający trwałe zachowanie jego wartości ${ }^{38}$. W związku z tym uznać można, że przestępstwo zniszczenia lub uszkodzenia zabytku z art. 108 u.o.z. może być popełnione przez zaniechanie przez właściciela lub posiadacza zabytku, na których spoczywa prawny, szczególny obowiązek zapobiegnięcia jego zniszczeniu bądź uszkodzeniu (przestępstwo indywidualne) ${ }^{39}$. Nawet jeśli na skutek zaniechań właściciela lub posiadacza do zniszczenia lub uszkodzenie jeszcze nie doszło, to może zaistnieć wykroczenie z art. 110 u.o.z., polegające na niezabezpieczeniu zabytku w należyty sposób przed uszkodzeniem, zniszczeniem, zaginięciem lub kradzieżą. Tego typu zjawiska odnotowuje się w szczególności na Warmii i Mazurach, gdzie znajduje się wiele zabytków po mieszkańcach dawnych Prus Wschodnich. Przykładami zanie-

\footnotetext{
35 L. Czerniak, op. cit., s. 116-122.
}

36 Na Warmii i Mazurach tego typu nieprawidłowości odnotowano m.in. podczas budowy drogi krajowej nr 7 w okolicach Olsztynka (cmentarz żołnierzy niemieckich poległych w bitwie pod Tannenbergiem w 1914 r. w Sudwie oraz obóz jeniecki Stalag 1B Hohenstein w Królikowie).

37 M. Trzciński, O niszczeniu zabytków..., s. 149; W. Pływaczewski, Degradacja krajobrazu jako szczególna forma wandalizmu ekologicznego - kontrowersje wokół lokalizacji farm wiatrowych na obszarach wyróżniających się cennymi walorami naturalnymi i kulturowymi, w: W. Pływaczewski, S. Buczyński (red.), Wandalizm wobec dziedzictwa naturalnego i kulturowego, Uniwersytet Warmińsko-Mazurski. Wydział Prawa i Administracji. Katedra Kryminologii i Polityki Kryminalnej, Olsztyn 2015, s. 15.

38 Obowiązki i powinności właścicieli i posiadaczy zabytków scharakteryzowano w: M. Gosztyła, P. Pásztor, Konserwacja i ochrona zabytków architektury, wyd. 2, Oficyna Wydawnicza Politechniki Rzeszowskiej, Rzeszów 2013, s. 67-76.

39 B. Gadecki, Karnoprawna ochrona zabytków architektury, w: W. Pływaczewski, S. Buczyński (red.), op. cit. s. 56. Odmienny, lecz odosobniony pogląd wyraża R. Golat w: R. Golat, Ustawa o ochronie zabytków i opiece nad zabytkami. Komentarz, Zakamycze, Kraków 2004, s. 193. 
dbań i bezczynności właścicieli,zarówno prywatnych, jaki Skarbu Państwa, mogą być pałace pruskich rodów szlacheckich - Lehndorffów w Sztynorcie, Dohnów w Gładyszach i Stobitach oraz Finckensteinów w Kamieńcu ${ }^{40}$. Analogiczne uwagi można odnieść do poniemieckich zamków i pałaców na Dolnym Śląsku i Pomorzu. Skłania to przedstawicielidoktryny do konstatacji,żenajsłabszymogniwem wsystemie ochrony dziedzictwa kulturowego są organy administracji samorządowej i urzędy konserwatorskie $^{41}$. Jednocześnie wskazuje się, że mimo funkcjonowania dość restrykcyjnych przepisów karnych w ustawie o ochronie zabytków i opiece nad zabytkami, jakość i stopień ich wykorzystania jest niewielki ${ }^{42}$. Zasadniczej jednak przyczyny zaniechań przez właścicieli i posiadaczy działań na rzecz ochrony własnych zabytków upatrywaćnależy waspektach merkantylnych. Administracja publiczna nie wspiera bowiem finansowo prywatnych właścicieli zabytków, co zniechęca ich do ponoszenia nakładów finansowych na ochronę zabytków. W efekcie ekonomicznie korzystniejsze jest dla właściciela uiszczenie kary grzywny niż np. finansowanie kosztownej renowacji zabytku ${ }^{43}$. W skrajnych wypadkach zjawisko to może przybierać formę świadomego doprowadzania przez właściciela zabytku do ruiny lub celowego burzenia z intencją uzyskania cennego gruntu, który już bez ingerencji konserwatora zabytków będzie mógł być wykorzystany w celach deweloperskich ${ }^{44}$. Ponadto sprawcy takich czynów czują się bezkarnie, ponieważ przestępstwa wymierzone przeciwko dziedzictwu kulturowemu często postrzegane są błędnie przez pryzmat niskiej szkodliwości czynu ${ }^{45}$.

\section{d) Wandalizm krajobrazu kulturowego}

Istotnym składnikiem dziedzictwa narodowego jest oprócz dziedzictwa kulturowego również dziedzictwo przyrodnicze. Elementem łączącym oba te elementy jest tzw. krajobraz kulturowy, zdefiniowany $w$ art. 3 pkt. 14 u.o.z. jako postrzegana przez ludzi przestrzeń, zawierająca elementy przyrodnicze i wytwory cywilizacji,

40 "Gładysze zachowały się w niezrujnowanym stanie do lat 80. XX w. W pałacu przechowywano zboże, a wyposażenie było rozszabrowane. Część dawnego wyposażenia jest dzisiaj w Muzeum Warmii i Mazur, a część została wywieziona poza Olsztyn". Tak sytuację pruskich rezydencji rodowych na przykładzie pałacu w Gładyszach opisał L. Czubiel - warmińsko-mazurski konserwator zabytków w latach 1960-1990 (I. Lewandowska, Konserwatorskie zwierzenia. Rozmowy z Lucjanem Czubielem konserwatorem zabytków w Olsztynie 1956-1993, Wydawnictwo Uniwersytetu Warmińsko-Mazurskiego, Olsztyn 2015, s. 199).

41 W. Pływaczewski, Zawłaszczanie przestrzeni..., s. 27-28.

42 M. Gosztyła, P. Pásztor, op. cit., s. 75.

43 A. Jagielska-Burduk, W.Szafrański, P. Lasik (red.),Zogniskowany wywiad grupowyjako metoda badania prawa ochrony dziedzictwa kultury, Wydawnictwo Uniwersytetu Kazimierza Wielkiego, Bydgoszcz 2016, s. 72-82.

44 Bulwersujący opinię publiczną przykład wyburzenia cennego zabytku nieruchomego w centrum Łodzi opisano w: J. Makiłła-Polak, Problematyka niszczenia zabytków nieruchomych w Polsce na przykładzie sprawy zburzenia willi na ulicy Zgierskiej w Łodzi, w: M. Trzciński, O. Jakubowski (red.), Przestępczość przeciwko dziedzictwu kulturowemu, Katedra Kryminalistyki Wydział Prawa, Administracji i Ekonomii Uniwersytetu Wrocławskiego, Wrocław 2016, s. 115-138.

45 K. Zeidler, P. Rybiński, Społeczna szkodliwość czynu a przestępstwa przeciwko dziedzictwu kultury, w: M. Trzciński, O. Jakubowski (red.), op. cit., s. 261-268. 
historycznie ukształtowana w wyniku działania czynników naturalnych i działalności człowieka ${ }^{46}$. Szczególną formą ochrony krajobrazu kulturowego jest natomiast park kulturowy ${ }^{47}$. W województwie warmińsko-mazurskim utworzono dotychczas tylko jeden taki chroniony obszar - Park Kulturowy Warmińskiej Drogi Krajobrazowej Gietrzwałd-Woryty, a w województwie podlaskim nie utworzono żadnego. Jednocześnie w krajobrazie Warmii, Mazur i Podlasia powstaje coraz więcej inwestycji budowlanych zagrażających ekosystemowi naturalnemu i kulturowemu ${ }^{48}$. W szczególności dotyczy to ogromnych farm wiatrowych. Ich lokalizacja planowana jest często $w$ bezpośrednim sąsiedztwie zabytków, np. sanktuarium maryjnego w Świętej Lipce lub średniowiecznego układu urbanistycznego Reszla. Podkreślenia wymaga, że budowa farm wiatrowych jest istotnym zagrożeniem dla całego ekosystemu. Negatywnymi następstwami tego typu inwestycji są m.in. dewastacja krajobrazu kulturowego i naturalnego, wandalizm ekologiczny, naruszenie ładu przestrzennego, wzrost bezrobocia na skutek obniżenia atrakcyjności turystycznej tych terenów czy pojawienie się tzw. syndromu turbiny wiatrowej ${ }^{49}$.

Podobnym, głośnym w Polsce, przykładem wandalizmu krajobrazu kulturowego była budowa ogromnego silosa cukrowego na osi widokowej barokowej, uznanej za pomnik historii, bazyliki na Świętej Górze w Gostyniu. Tego typu zawłaszczanie, degradację i dewastowanie krajobrazu kulturowego kryminolodzy, zwłaszcza reprezentujący nurt tzw. ekokryminologii, uznają za wandalizm dziedzictwa kulturowego i przyrodniczego ${ }^{50}$.

Podkreślić należy, że już w dekrecie z 1918 r. w art. 17 stwierdzono, iż „rząd ma prawo nie dopuścić do zniszczenia, zasłaniania lub szpecenia widoku na zabytki lub z zabytków nieruchomych". Jak nowatorskie i perspektywiczne było to rozwiązanie, świadczą opisane wyżej współczesne problemy ochrony krajobrazowych walorów zabytków ${ }^{51}$. W myśl art. 6 ust. 1 pkt 1 lit. a u.o.z., krajobraz kulturowy może być zaliczony do zabytków nieruchomych. Jak podkreśla się w literaturze, oprócz wartości historycznej, artystycznej lub naukowej jednym z walorów, jaki może mieć zabytek, jest wartość krajobrazowa ${ }^{52}$.

\footnotetext{
46 J. Pruszyński zdefiniował krajobraz kulturowy jako „krajobraz, w którym elementy naturalne i dzieła rąk ludzkich harmonizują ze sobą" i pojęciu temu przeciwstawiał termin "krajobraz zdewastowany”. J. Pruszyński, Ochrona zabytków w Polsce. Geneza. Organizacja. Prawo, PWN, Warszawa 1989, s. 22.

47 T.Bąkowski, Krajobraz kulturowy, w: K.Zeidler (red.), Leksykon prawa ochrony zabytków. 100 podstawowych pojęć, C. H. Beck, Warszawa 2010, s. 142-144; M. Drela, Park kulturowy, w: K. Zeidler (red.), Leksykon prawa ochrony zabytków..., C.H. Beck, Warszawa 2010, s. 248-256.

48 W literaturze wskazuje się na stopniowe zbliżanie się na gruncie prawnym instytucji krajobrazu przyrodniczego i krajobrazu kulturowego. Zob. D. Kostrzewa, Krajobraz przyrodniczy a krajobraz kulturowy porównanie instytucji prawnych, w: W. Pływaczewski, B. Gadecki (red.), op. cit., s. 55-62.

49 W. Pływaczewski, Degradacja krajobrazu..., s. 13-38.

50 Idem, Zawłaszczanie przestrzeni..., s. 14-15.

51 Szerzej w: J. Pruszyński, Prawna ochrona zabytków architektury w Polsce, Wydawnictwo Prawnicze, Warszawa 1977, s. 27-28.

52 K. Zeidler, Wartość zabytku jako kategoria normatywna, w: W. Szafrański (red.), op. cit., s. 45.
} 
Pod dyskusję zatem można poddać kwestię, czy prawnokarną ochroną na gruncie art. 108 u.o.z. objęte powinny być jedynie te krajobrazy kulturowe, które są objęte ochroną w ramach parków kulturowych, czy również te, dla których nie ustanowiono takiej formy ochrony? Jak wskazuje Jan Pruszyński, krajobraz jest bowiem kategorią trudną zarówno do zdefiniowania, jak i ochrony prawnej, a tym bardziej wpisu do jakiegokolwiek rejestru publicznego ${ }^{53}$.

Ponadto, jak wskazują badania aktowe dotyczące niszczenia zabytków, jednym $z$ najczęściej popełnianych $w$ województwie warmińsko-mazurskim przestępstw o charakterze wandalskim wpisujących się w destrukcję krajobrazu jest wyrąb drzew z zabytkowych parków przypałacowych ${ }^{54}$.

\section{Wnioski}

Mając na uwadze przytoczone przykłady, należy stwierdzić, że wyczerpujące opisanie zjawiska wandalizmu zabytków wymaga rozszerzenia klasycznej definicji wandalizmu przytoczonej na wstępie o dwa aspekty. Wandalizm tego typu obejmuje bowiem nie tylko niszczenie mienia cudzego lecz również dotyczyć może mienia należącego do sprawcy, czego przykładem jest np. typizacja przestępstwa $z$ art. 108 u.o.z. Ponadto sprawca tej odmiany wandalizmu nie zawsze działa bez czytelnej intencji. Nierzadko może także kierować się określonymi, klarownymi powodami, uchwytnymi również dla osoby oceniającej takie działania. W związku z tym różne odmiany wandalizmu dziedzictwa kulturowego wpisują się w zaproponowaną przez S. Cohena typologię wandalizmu ze względu na motyw i cel działania sprawcy, taki jak: zaborczy, taktyczny, ideologiczny, mściwy, zabawowy lub złośliwy.

Konfrontując ze sobą definicje wandalizmu przytoczone we wstępie oraz przedstawione następnie formy objawowe tego zjawiska wymierzone w dziedzictwo kulturowe, zaproponować można definicję uwzględniającą specyfikę przestępczości przeciwko zabytkom. Pojęciem wandalizmu zabytków można zatem określić niezależne od powodów zachowania sprawcy umyślne niszczenie lub uszkadzanie zabytków własnych lub cudzych, popełnione z działania lub zaniechania. Poza zakresem pojęcia wandalizmu zabytków pozostaje natomiast niewątpliwie nieumyślne ich niszczenie lub uszkadzanie, mimo że takie zachowanie się sprawcy jest kryminalizowane na gruncie art. 108 § 2 u.o.z.

Nawiązując do toczącej się w literaturze przedmiotu dyskusji nad samodzielnością prawa ochrony dziedzictwa kultury, stwierdzić można, że uznając istnienie nowej gałęzi prawa w postaci prawa ochrony dziedzictwa kultury, uwzględnić należy również wyodrębnienie się nowej, wyspecjalizowanej formy przestępczości, okre-

\footnotetext{
53 J.Pruszyński, Dziedzictwo kultury Polski. Jego straty i ochrona prawna, t. 1,Zakamycze, Kraków 2001, s. 86

54 E. Kałędek, B. Gadecki, Przestępczość przeciwko zabytkom. Wnioski po analizie akt spraw sądowych, w: M. Trzciński, O. Jakubowski (red.), op. cit., s. 247-260.
} 


\section{ARTYKUŁY}

Joanna Narodowska, Maciej Duda

ślanej jako przestępczość przeciwko dziedzictwu kulturowemu ${ }^{55}$. W związku z tym jednym z zadań współczesnej kryminologii jest diagnozowanie i monitorowanie zagrożeń wymierzonych w dziedzictwo kulturowe, a także poszukiwanie skutecznych metod przeciwdziałania im.

\section{Bibliografia}

Bąkowski T., Krajobraz kulturowy, w: K. Zeidler (red.), Leksykon prawa ochrony zabytków. 100 podstawowych pojęć, C.H. Beck, Warszawa 2010.

Błachut J., Gaberle A., Krajewski K., Kryminologia, Arche, Gdańsk 2001.

Bursche A., Złodzieje i paserzy, dogmatycy i moraliści, „Światowid” 2000, nr 2(43).

Czajkowska E., Truskolaska M., Wandalizm dzieł sztuki jako wizualny przejaw nienawiści na przykładzie województwa podlaskiego, w: W. Pływaczewski, P. Lubiewski (red.), Współczesne ekstremizmy. Geneza, przejawy, przeciwdziałanie, Katedra Kryminologii i Polityki Kryminalnej. Wydział Prawa i Administracji Uniwersytetu Warmińsko-Mazurskiego, Olsztyn 2014.

Czerniak L., Niechciane zabytki archeologiczne, w: J. Włodarski, K. Zeidler (red.), Prawo muzeów, Wolters Kluwer Polska, Warszawa 2008.

Dekret Rady Regencyjnej z dnia 31 października 1918 r. o opiece nad zabytkami sztuki i kultury, „Dziennik Praw” 1918, nr 16.

Drela M., Park kulturowy, w: K. Zeidler (red.), Leksykon prawa ochrony zabytków. 100 podstawowych pojęć, C.H. Beck, Warszawa 2010.

Duda M., Nielegalne poszukiwania zabytków jako zagrożenie dla dziedzictwa kulturalnego, w: W. Pływaczewski, B. Gadecki (red.), Ochrona dziedzictwa kulturalnego i naturalnego. Perspektywa prawna i kryminologiczna, C.H. Beck, Warszawa 2015.

Duda M., Narodowska J., Eksploracja archeologiczna obszarów leśnych, w: W. Pływaczewski, M. Duda (red.), Nielegalna eksploatacja obszarów leśnych, Katedra Kryminologii i Polityki Kryminalnej. Wydział Prawa i Administracji. Uniwersytet Warmińsko-Mazurski, Olsztyn 2013.

Gadecki B., Karnoprawna ochrona zabytków architektury, w: W. Pływaczewski, S. Buczyński (red.), Wandalizm wobec dziedzictwa naturalnego i kulturowego, Uniwersytet Warmińsko-Mazurski. Wydział Prawa i Administracji. Katedra Kryminologii i Polityki Kryminalnej, Olsztyn 2015.

Gadecki B., Ochrona podwodnego dziedzictwa kultury - aspekty prawnokarne i kryminologiczne, C.H. Beck, Warszawa 2014.

Gadecki B., Ustawa o ochronie zabytków i opiece nad zabytkami. Art. 108-120. Przepisy karne. Komentarz, C.H. Beck, Warszawa 2014, s. VII.

Gerecka-Żołyńska A., Rozważania wokół współczesnych problemów karnoprawnej i karnoprocesowej ochrony zabytków, w: W. Szafrański (red.), Wokół problematyki prawnej zabytków i dzieł sztuki, t. 2, Wydawnictwo Poznańskie, Poznań 2008, s. 134.

Golat R., Ustawa o ochronie zabytków i opiece nad zabytkami. Komentarz, Zakamycze, Kraków 2004.

55 Wydaje się, że nazwa tej wyodrębnionej gałęzi przestępczości została ugruntowana i zaakceptowana wdoktrynie, oczym świadczyćmogą chociażby tytuły publikacji takichjak: M. Trzciński, O. Jakubowski (red.), op. cit. 
Gosztyła M., Pásztor P., Konserwacja i ochrona zabytków architektury, wyd. 2, Oficyna Wydawnicza Politechniki Rzeszowskiej, Rzeszów 2013, s. 67-76.

Hołyst B., Przyczyny i przejawy wandalizmu, w: B. Hołyst (red.), Wandalizm. Aspekty socjologiczne, psychologiczne i prawne, PWN, Warszawa 1984.

Jagielska-Burduk A., Szafrański W., Lasik P. (red.), Zogniskowany wywiad grupowy jako metoda badania prawa ochrony dziedzictwa kultury, Wydawnictwo Uniwersytetu Kazimierza Wielkiego, Bydgoszcz 2016.

Kaczmarek J., Zeidler K., Prawnokarna ochrona zabytków, „Prokuratura i Prawo” 2004, nr 2.

Kałędek E., Gadecki B., Przestępczość przeciwko zabytkom. Wnioski po analizie akt spraw sądowych, w: M. Trzciński, O. Jakubowski (red.), Przestępczość przeciwko dziedzictwu kulturowemu, Katedra Kryminalistyki Wydział Prawa, Administracji i Ekonomii Uniwersytetu Wrocławskiego, Wrocław 2016.

Kostrzewa D., Krajobraz przyrodniczy a krajobraz kulturowy - porównanie instytucji prawnych, w: W. Pływaczewski, B. Gadecki (red.), Ochrona dziedzictwa kulturalnego i naturalnego. Perspektywa prawna i kryminologiczna, C.H. Beck, Warszawa 2015.

Kostrzewski B., Ochrona zabytków przedhistorycznych, „Czytelnik”, Łódź 1948.

Kowalski W., Cywilnoprawne aspekty obrotu skradzionymi dobrami kultury, w: J. Kaczmarek (red.), Prawnokarna ochrona dziedzictwa kultury, Zakamycze, Kraków 2006.

Lewandowska I., Konserwatorskie zwierzenia. Rozmowy z Lucjanem Czubielem konserwatorem zabytków w Olsztynie 1956-1993, Wydawnictwo Uniwersytetu Warmińsko-Mazurskiego, Olsztyn 2015.

Lewicka M., W świecie zabytków sztuki, Wydawnictwa Szkolne i Pedagogiczne, Warszawa 1976.

Łukaszewicz-Jędrzejewska E., Trudne dziedzictwo - zabytki Dolnego Śląska „jako źródło kształtowania i wychowania nowego człowieka", w: E. Pilecka, J. Raczkowski (red.), Wobec zabytku... tradycje i perspektywy postaw, Wydawnictwo Naukowe Uniwersytetu Mikołaja Kopernika, Toruń 2010.

Makiłła-Polak J., Problematyka niszczenia zabytków nieruchomych w Polsce na przykładzie sprawy zburzenia willi na ulicy Zgierskiej w Łodzi, w: M. Trzciński, O. Jakubowski (red.), Przestępczość przeciwko dziedzictwu kulturowemu, Katedra Kryminalistyki Wydział Prawa, Administracji i Ekonomii Uniwersytetu Wrocławskiego, Wrocław 2016.

Marcinkowska M., Rewindykacja muzealiów z Rosji, w: J. Włodarski, K. Zeidler (red.), Prawo muzeów, Wolters Kluwer Polska, Warszawa 2008.

Nowakiewicz T. (red.), Archeologiczne dziedzictwo Prus Wschodnich w archiwum Feliksa Jakobsona, Ministerstwo Kultury i Dziedzictwa Narodowego. Departament Dziedzictwa Kulturowego, Warszawa 2011.

Ogrodzki P., Przestępczość przeciwko zabytkom (krótka charakterystyka zjawiska), w: M. Karpowicz, P. Ogrodzki (red.), Międzynarodowa współpraca służb policyjnych, granicznych i celnych w zwalczaniu przestępczości przeciwko zabytkom, Wydział Wydawnictw Wyższej Szkoły Policji, Szczytno 2005.

Ostrowska K., Psychologiczne aspekty wandalizmu nieletnich, w: B. Hołyst (red.), Wandalizm. Aspekty socjologiczne, psychologiczne i prawne, PWN, Warszawa 1984.

Pływaczewski W., Degradacja krajobrazu jako szczególna forma wandalizmu ekologicznego kontrowersje wokół lokalizacji farm wiatrowych na obszarach wyróżniających się cennymi walorami naturalnymi i kulturowymi, w: W. Pływaczewski, S. Buczyński (red.), Wandalizm wobec dziedzictwa naturalnego i kulturowego, Uniwersytet Warmińsko-Mazurski. Wydział Prawa i Administracji. Katedra Kryminologii i Polityki Kryminalnej, Olsztyn 2015. 


\section{ARTYKUŁY}

Joanna Narodowska, Maciej Duda

Pływaczewski W., Wandalizm wobec dziedzictwa kulturowego jako przejaw nienawiści o podłożu ideologicznym, w: M. Różański, N. Kasparek (red.), Ochrona dóbr kultury. Aktualne wyzwania, Archidiecezjalne Wydawnictwo Łódzkie, Olsztyn 2016.

Pływaczewski W., Wandalizm z perspektywy ochrony dziedzictwa kultury - diagnoza zjawiska oraz możliwości przeciwdziałania, w: K. Zeidler (red.), Prawo ochrony zabytków, Wolters Kluwer, Wydawnictwo Uniwersytetu Gdańskiego, Warszawa - Gdańsk 2014.

Pływaczewski W., Zawłaszczanie przestrzeni przyrodniczej i kulturowej - uwagi na tle zjawiska dewastacji krajobrazu, w: W. Pływaczewski, B. Gadecki (red.), Ochrona dziedzictwa kulturalnego i naturalnego. Perspektywa prawna i kryminologiczna, C.H. Beck, Warszawa 2015.

Pruszyński J., Dziedzictwo kultury Polski. Jego straty i ochrona prawna, t. 1, Zakamycze, Kraków 2001.

Pruszyński J., Ochrona zabytków w Polsce. Geneza. Organizacja. Prawo, PWN, Warszawa 1989.

Pruszyński J., Prawna ochrona zabytków architektury w Polsce, Wydawnictwo Prawnicze, Warszawa 1977.

Radecki W., Ochrona dóbr kultury w nowym kodeksie karnym, „Prokuratura i Prawo” 1998, nr 2.

Rozporządzenie Prezydenta Rzeczypospolitej z dnia 6 marca 1928 r. o opiece nad zabytkami, Dz. U. Nr 29, poz. 265.

Siemaszko A., Wandalizm - definicja, etiologia, zapobieganie, w: B. Hołyst (red.), Wandalizm. Aspekty socjologiczne, psychologiczne i prawne, PWN, Warszawa 1984.

Szacki J., Ideologia, w: A. Kłoskowska (red.), Encyklopedia kultury polskiej XX wieku, t. 1: Pojęcia i problemy wiedzy o kulturze, „Wiedza o Kulturze”, Wrocław 1991.

Trzciński M. (red.), Archeologia sądowa w teorii i praktyce, Wolters Kluwer Polska, Warszawa 2013.

Trzciński M., Kryminalistyczne i kryminologiczne aspekty przestępstw przeciwko zabytkom archeologicznym, „Państwo i Prawo” 2007, nr 3.

Trzciński M., O niszczeniu zabytków, w: W. Pływaczewski, B. Gadecki (red.), Ochrona dziedzictwa kulturalnego i naturalnego. Perspektywa prawna i kryminologiczna, C.H. Beck, Warszawa 2015.

Ustawa z dnia 15 lutego 1962 r. o ochronie dóbr kultury, Dz. U. Nr 10, poz. 48.

Ustawa z dnia 20 maja 1971 r. Kodeks wykroczeń, tekst jedn. Dz. U. z 2015 r., poz. 1094, ze zm.

Ustawa z dnia 23 lipca 2003 r. o ochronie zabytków i opiece nad zabytkami, tekst jedn. Dz. U. z 2014 r., poz. 1446.

Ustawa z dnia 6 czerwca 1997 r. Kodeks karny, Dz. U. Nr 88, poz. 553 ze zm.

Waltoś S., Grabież ołtarza Wita Stwosza, Wolters Kluwer, Warszawa 2015.

Wandalizm [hasło], w: M. Szymczak (red.), Słownik języka polskiego, t. III, Warszawa 1979.

Zeidler K., Wartość zabytku jako kategoria normatywna, w: W. Szafrański (red.), Wokół problematyki prawnej zabytków i dzieł sztuki, t. 2, Wydawnictwo Poznańskie, Poznań 2008.

Zeidler K., Rybiński P., Społeczna szkodliwość czynu a przestępstwa przeciwko dziedzictwu kultury, w: M. Trzciński, O. Jakubowski (red.), Przestępczość przeciwko dziedzictwu kulturowemu, Katedra Kryminalistyki Wydział Prawa, Administracji i Ekonomii Uniwersytetu Wrocławskiego, Wrocław 2016.

Zeidler K., Trzciński M., Wykład prawa dla archeologów, Wolters Kluwer Polska, Warszawa 2009. 